九州大学学術情報リポジトリ

Kyushu University Institutional Repository

\title{
Land Value Capture: Defining Crucial Variables Difference-in-Differences Model for Residential Properties Surrounding MRT Jakarta Stage I
}

Mohammed Ali Berawi

Department of Civil Engineering, Faculty of Engineering, Universitas Indonesia

Darmawan, Alexander

Department of Civil Engineering, Faculty of Engineering, Universitas Indonesia

Gunawan

Department of Civil Engineering, Faculty of Engineering, Universitas Indonesia

Miraj, Perdana

Department of Civil Engineering, Faculty of Engineering, Universitas Indonesia

他

https://doi.org/10.5109/4055228

出版情報 : Evergreen. 7 (2)，pp.253-261，2020-06. 九州大学グリーンテクノロジー研究教育センター バージョン：

権利関係 : 


\title{
Land Value Capture: Defining Crucial Variables Difference- in-Differences Model for Residential Properties Surrounding MRT Jakarta Stage I
}

\author{
Mohammed Ali Berawi 1,*, Alexander Darmawan ${ }^{1}$, Gunawan ${ }^{1}$, Perdana Miraj ${ }^{1}$, \\ Hamzah Abdul Rahman ${ }^{2}$ \\ 1 Department of Civil Engineering, Faculty of Engineering, Universitas Indonesia, Depok 16424, Indonesia \\ 2 Department of Quantity Surveying, Faculty of Built Environment, University of Malaya, Malaysia
}

*Author to whom correspondence should be addressed:

E-mail: maberawi@eng.ui.ac.id

(Received October 30, 2019; Revised May 2, 2020; accepted May 21, 2020).

\begin{abstract}
Positive effect on property value can be gained from the development of public transportation system. This study is aimed to identify the variables that affect the residential property price around the first phase of the Jakarta MRT station project construction. The variables were based on the data of Land \& Building Tax Imposition Base (NJOP). From the statistical analysis (multi collinearity, paired T, ANOVA, and normality test), it is found that variables significantly affecting the residential property price are unit area, shared building, shared land, land area, building area, density, distance to MRT/CBD/hospital/favorite high school, and public park.
\end{abstract}

Keywords: Land Value Capture; Residential Property; MRT

\section{Introduction}

Indonesia is the $4^{\text {th }}$ most populous country in the world, with about 265 million people, according to the 2018 census and projected to be the $6^{\text {th }}$ largest economy by 2023 . However, to support its economic growth, many infrastructures need to be provided by the government ${ }^{1)}$. As the center of economic growth, the city provides public facilities and employment opportunities that attract people to move from rural to urban areas. Also, urban population growth has implications for the number of trips made by residents to meet their needs. Therefore, a transportation system is needed to reduce the number of vehicles on the road to avoid heavy congestion.

Based on this problem, in 2015, Badan Pengelola Transportasi JABODETABEK (BPTJ) or the Transportation Management Agency of JABODETABEK was formed to integrate public transportation in JABODETABEK. Also, BPTJ provides recommendations for spatial planning oriented to mass public transportation, by issuing public transport licenses exceeding provincial boundaries in Jakarta, Bogor, Depok, Tangerang, and Bekasi regions, with recommendations for feeder services. Komite Percepatan Penyediaan Infrastruktur Prioritas (KPPIP) also known as the Committee on Acceleration of Provision of Priority Infrastructure was formed in 2015 with the main objective of coordinating units in decision making processes and encouraging the resolution of problems arising from the lack of effective cooperation of various stakeholders. KPPIP is a point of contact in implementing coordination to avoid debottlenecking on National Strategic Projects and Priority Projects and consists of three urban transportations covering Jakarta MRT (south-north line)2), Jakarta LRT, Bogor, Depok, Bekasi Circular Line ${ }^{3)}$, and Palembang LRT ${ }^{4}$. The establishment of supporting institutions and the construction of numerous public transportations indicates how important the transit system is in urban areas.

Rail-based transportation projects are not infrastructure with low investment costs. Therefore, based on KPPIP, the Jakarta MRT is divided into two construction phases, each of which has an investment value of 17 and 22.5 trillion rupiahs with funding sources from the APBN (State Budget), DKI Jakarta Provincial Budget, and foreign loans. In 2017 the state budget provided based on state financial reports, amounted to 2,080.5 trillion rupiahs, with 378 trillion of the total amount used for economic infrastructure and mass transportation. However, due to the high cost of investment in mass transportation, the government uses funding schemes to exceed the limitation of the budget. This scheme is also needed because the government does not directly acquire income from the mass transportation/transit system otherwise it needs to bear the burden of operational costs and repairs without ruling out ticket prices subsidization to be affordable. It is very ironic to see the government incur huge costs as an investment while landowners near the transit station have very large profits in terms of their land. Based on this 
phenomenon, a Land Value Capture scheme is needed to capture the value of land adjacent to the transit station either through taxes or other systems.

Various studies have been conducted to determine the land uplift magnitude due to the existence of a transit system, one of which was conducted in Toronto, Canada. This study was carried out to identify the increases in prices of commercial, industrial, residential, and other properties within an 800-meter radius from the transit station. Based on the conclusions of the study, the total increase near the transit area was divided into two categories. The first is the effect of a specific TOD station, which increases by $20 \%$, while the second is due to the proximity effect of the property to the transit station with a greater increasing value assuming it is adjacent to the transit station ${ }^{5)}$. This study shows that the increases in land differ by the location characteristics, such as inner, outer, and suburban neighborhoods.

In implementing the Land Value Capture scheme, the identification of variables that significantly affect the property value needs to be done ${ }^{6}$ ), so that instead of being biased, the application of LVC scheme to land or property owned by private is based on the response of the property market during the construction phase of the transit system. Therefore, this study is conducted to identify which variables that can affect the increase in land/ property values around the MRT station, which at the time of this research is still in the first phase of development.

\subsection{Transit Infrastructure and Transit-Oriented Development (TOD)}

Railroad infrastructure is categorized as critical by the United States. This is due to the fact that cities and metropolitan areas are the centers of various activities that require transportation of goods or people effectively and easily from one place to another. It is also often said that transportation is a component that revives a city. Therefore, the activities carried out by residents with high density causes the need for modes with large capacity and efficient energy. Public transportation serves everyone, while private vehicles are used individually. Also, the need for public transportation appears to reduce the space required for transportation and lowers congestion. This train transportation system is also often referred to as the train transit system.

According to ${ }^{7)}$, the transit system is divided into three categories, namely private, rental, and public or mass transportation/transit. In private transportation, modes such as cars, bicycles, and pedestrians, are privately owned and operated by the private sector. Rental transportation is operated by other people but is individually enjoyed such as rented taxis and buses, while public transportation is a fixed transportation route which stops in a short time.

Based on the intervention of other modes and its activity, the transit system is divided into three categories, namely, the street, semi-rapid, and rapid transit system ${ }^{7)}$. The first is slower than traffic conditions in general and cannot compete with private vehicles unless there are restrictions or emphasis on their use with the tram system as an example. However, this system cannot be implemented in Indonesia, which has congested roads but operates very well in Melbourne. The semi-rapid transit system intersects with public roads, thereby experiences interference from general traffic such as the Transjakarta and commuter line systems in Indonesia. Finally, the Rapid Transit system is not disturbed by any mode and does not have uninterrupted lines such as the LRT and MRT Jakarta.

There are various reasons for the above classification of the transportation system. For instance, its type provides a different level of timeliness, comfort, and reliability. Furthermore, the Jakarta's LRT and MRT infrastructure are classified as public transportation and Rapid Transit, with timeliness, comfort, and a high level of trust thereby, providing it with a high number of passengers which are the basis for the development of Transit-OrientedDevelopment. This was developed to help government investment return in the relatively expensive transit system.

Apart from the above reasons, TOD, which was initiated by the existence of the transit system, also provides additional benefits by concentrating on human activities in a particular area and increasing its density ${ }^{8}$. Under the World Heritage Institute, the low population and the spread of urban areas, which increases the cost of infrastructure and maintenance requires additional costs because people tend to travel longer distances. In 2013, it was noted that congestion in the metropolitan area of Sao Paulo and Rio de Janeiro harmed Brazil by 98 billion Brazilian dollars, which is equivalent to $2 \%$ of its GDP that year. This number, however, excluded the cost acquired due to accidents and health effects. Therefore, railroad infrastructure has become a necessity for a sustainable $^{9)}$ and resilient city ${ }^{10)}$.

\subsection{Transit Infrastructure and Land Value Capture (LVC)}

Most mass transit systems, such as MRT and LRT are financed and subsidized by the government. These subsidies lead to higher taxes and reduce funds for other public facilities. The uplift of land around the transit station is underutilized as a source of funds for return on capital ${ }^{11)}$. The transit system benefits are used for economic value, with the provider not fully depending on funds from government subsidies for the initial investment and the operation of the system.

The issue of using land valuation to finance public investment in infrastructure and especially in public transportation has received interest from academicians and practitioners in recent years. According to ${ }^{12)}$, Land Value Capture (LVC) is a method of infrastructure financing carried out by taking the land generated from infrastructural development in certain areas ${ }^{13)}$. LVC helps 
cities mitigate challenges in financing public infrastructure and also provide benefits to private sectors 14). The aim of developing research on LVC is due to the high investment in public transportation, thereby making it a requirement used to finance all or part of the cost of local transportation projects ${ }^{15}$. Various studies have been conducted and show that buyers are willing to pay for premium, commercial, and residential properties, in densely populated areas ${ }^{11)}$. Due to this, governments in various countries, such as the UK, Hong Kong, Japan, Australia, and others, utilize this system to retrieve values created by the building infrastructures. Capture Land Value is a variation and collection that is based on a system where property owners' benefit from infrastructure provided by the government pay a portion of the public development costs to where it originates.

Transportation infrastructure projects, through demand mechanisms, create value which increases in the land ${ }^{16,17)}$. This request mechanism recognizes that the demand for land is partly due to the accessibility of an area, therefore, making users willing to pay for additional access. This request mechanism is used to show the relationship between distance and access from transportation infrastructure. In general, the farther the distance to the station, the smaller the benefits associated with its accessibility. However, the relationship between the distance to the station and the increase in value is not the same for all fields. Also, the negative effects of transportation infrastructure, such as noise and air pollution as well as increased crime, are centered on the station's point.

Increase in value against time is an element that needs to be included when implementing land value capture. According to ${ }^{17)}$, an increase in land values occurs at different phases of the infrastructure life cycle. This theoretical model implies that there are expectations associated with the benefits of transportation infrastructure, such as an increase in the value of land close to the area. Future growth only occurs assuming

there is existing infrastructure development, such as networks.

Relevant stakeholders, such as local governments need to consider various financing options before deciding the most appropriate method for a city concerning transportation investments. In the context of accessibility as the creator of value, it should be noted that transportation investment has direct and indirect impacts on the three components of capitalized land ${ }^{12)}$. Knowledge of this component is very important when determining the value to be utilized. For example, assuming the government invests in a transit system in an area, then the surrounding land tends to capitalize on the ease of access to the component responsible. The capitalization of land based on accessibility consists of urban areas, social and other infrastructures ${ }^{18)}$. Certainly, to determine the accessibility effect, variables from social infrastructure and other infrastructure need to be properly identified ${ }^{19)}$.

Transportation investment sometimes shows mixed results about the impact on property values. The existence of public access induces premium property values with a range between $3 \%$ and $40 \%$ for different reasons ${ }^{12,20)}$. Also, the positive effects of improved accessibility include saving travel time, higher access to the labor market, retail and cultural opportunities, and reasonable walking distance to the station. However, transportation investments also hurt properties due to increased negative externalities such as noise, pollution, station insensitivity, and crime. All of these components need to be properly defined to ensure that the modeling represents the actual situation.

\section{Methods}

\subsection{Variables}

The property valuation model in this study uses land prices per square meter as the dependent variable and transformed into a natural logarithmic form which reduces the scale of property to eliminate heteroscedasticity due to the large number ${ }^{21)}$.While the independent variable describes the characteristics of the land, which is assumed to be a consideration for property owners in accessing their assets ${ }^{22}$. The independent variables are shown in table 1. 
Table 1. Variables Description

\begin{tabular}{|c|c|c|}
\hline Variable & Description & Unit \\
\hline \multicolumn{3}{|c|}{ Dependent Variable } \\
\hline $\mathrm{P}$ & Property price & Rupiah $/ \mathrm{m}^{2}$ \\
\hline \multicolumn{3}{|c|}{ Independent Variables } \\
\hline \multicolumn{3}{|c|}{ Accessibility Attributes } \\
\hline D_MRTJ & Distance to MRT J Station & Meter \\
\hline D_Mall & Distance to Mall & Meter \\
\hline D_Hospital & Distance to Hospital & Meter \\
\hline D_PublicPark & Distance to the public park & Meter \\
\hline D_F.Highschool & Distance to Favorite High school & Meter \\
\hline D_F.Uni & Distance to Favorite University & Meter \\
\hline \multicolumn{3}{|c|}{ Structural Attribute } \\
\hline UA & Total Area of apartment unit; 0 if housing & $\mathrm{m}^{2}$ \\
\hline SBA & $\begin{array}{l}\text { Total owned shared building area for the } \\
\text { apartment; } 0 \text { if housing }\end{array}$ & $\mathrm{m}^{2}$ \\
\hline SLA & $\begin{array}{l}\text { Total owned shared land area for the } \\
\text { apartment; } 0 \text { if housing }\end{array}$ & $\mathrm{m}^{2}$ \\
\hline BA & Total building area of housing; 0 if the unit & $\mathrm{m}^{2}$ \\
\hline LA & The total land area of housing; 0 if the unit & $\mathrm{m}^{2}$ \\
\hline \multicolumn{3}{|c|}{ Neighborhood Attribute } \\
\hline Dens & The density of the area & Person $/ \mathrm{m}^{2}$ \\
\hline
\end{tabular}

\subsection{Data and Sources}

The dependent variable used in this study is the price per square meter of residential properties located around the Jakarta MRT station in stage 1 . This data was obtained from the Local Tax and Retribution Service Unit or Unit Pelayanan Pajak dan Retribusi Daerah (UPPRD) that evaluates property prices based on transactions each year to determine its tax. The data gives the size of properties, prices, and coordinates, which are then inputted to ArcGis to obtain the nearest distance to the infrastructures, which already defined the initial input. The amount of data obtained is more than 8600 from 2009 to 2018, and also the residential property prices, structural attributes, such as unit area, owned shared building area, owned shared land area, building area, and land area, were also provided by UPPRD DKI Jakarta. The descriptive data statistic is shown in tables 2 and 3

Table 2. Apartment's Descriptive Statistic

\begin{tabular}{llrrrr}
\hline & N & \multicolumn{1}{c}{ Min } & \multicolumn{1}{c}{ Max } & \multicolumn{1}{c}{ Mean } & \multicolumn{1}{c}{ Std. Dev. } \\
\hline P & 573 & $5,179,102$ & $48,706,093$ & $13,805,416$ & $6,200,540$ \\
Ln_P & 573 & 15.46 & 17.70 & 16.35 & 0.42 \\
UA & 573 & 11.00 & 767.00 & 133.36 & 94.45 \\
SBA & 573 & 6.00 & 585.00 & 55.77 & 49.09 \\
SLA & 573 & 3.00 & 206.00 & 55.16 & 50.76 \\
Dens & 573 & 11,015 & 18,344 & $13,333.87$ & $3,154.97$ \\
D_MRTJ & 573 & 178.07 & $3,185.17$ & 678.33 & 396.05 \\
D_CBD & 573 & 83.86 & $7,498.46$ & 2585.24 & 2546.63 \\
D_MALL & 573 & 38.82 & 2204.93 & 759.50 & 473.86 \\
D_Hospital & 573 & 74.37 & 1646.46 & 824.37 & 409.32 \\
D_F.Highschool & 573 & 117.82 & $6,498.90$ & $3,114.08$ & $1,242.75$ \\
D_PublicPark & 573 & 308.96 & 2722.33 & 1175.52 & 463.33 \\
D_F.Uni & 573 & 92.31 & 3220.82 & 811.95 & 533.87 \\
\hline
\end{tabular}


Table 3. Housing's Descriptive Statistic

\begin{tabular}{lrrrrr}
\hline & $\mathrm{N}$ & \multicolumn{1}{c}{ Min } & \multicolumn{1}{c}{ Max } & \multicolumn{1}{c}{ Mean } & Std. Deviation \\
\hline P & 8049 & $7,653.000$ & $123,608,294.118$ & $9,762,240.393$ & $7,399,448.628$ \\
Ln_P & 8049 & 8.943 & 18.633 & 15.869 & 0.673 \\
BA & 8049 & 16.000 & $1,058.000$ & 213.370 & 136.652 \\
LA & 8049 & 17.000 & $1,700.000$ & 275.860 & 164.785 \\
Dens & 8049 & $11,015.000$ & $18,344.000$ & $13,771.540$ & $3,149.643$ \\
D_MRTJ & 8049 & 67.450 & $11,740.889$ & 718.720 & 648.807 \\
D_CBD & 8049 & 96.547 & $17,553.027$ & $2,564.673$ & $2,518.404$ \\
D_MALL & 8049 & 129.603 & $10,571.072$ & 780.728 & 556.819 \\
D_Hospital & 8049 & 51.845 & $5,753.335$ & 890.737 & 493.056 \\
D_F.Highschool & 8049 & 217.131 & $7,109.901$ & $3,176.186$ & $1,522.631$ \\
D_PublicPark & 8049 & 23.973 & $4,340.030$ & 987.175 & 454.515 \\
D_F.Uni & 8049 & 18.524 & $4,966.306$ & 807.494 & 747.757 \\
\hline
\end{tabular}

Accessibility attributes were collected using Geographic Information System (GIS) by entering the coordinates of residential property and accessibility variables in the software. Furthermore, the GIS calculated the closest distance to each object of accessibility variable. The neighborhood variable and density were found on the open-source website of the DKI Jakarta government.

\subsection{Statistical Analysis}

Statistical tests are used to eliminate variables with no significant effect to make the model simple and capable of representing the data. All of these statistical tests use statistic software, namely IBM SPSS 23.

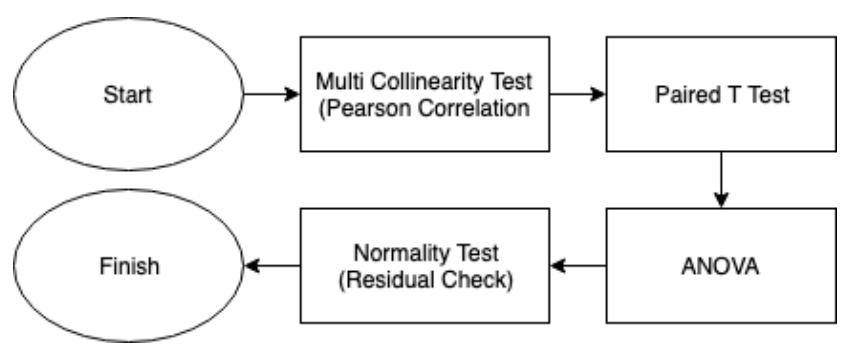

Fig 1: Statistical Analysis Flowchart

The order of the statistical test for variables is seen in figure 1 . The normality test aims to examine the residual or disturbing variable has a normal distribution in the regression model. It is known that the $t$ and $f$ (ANOVA) tests assume that the residual follows a normal distribution.

Multicore linearity test using Pearson Correlation is conducted to determine the relationship between independent variables indicated by the results matrix. This need to be carried out as a condition of multiple linear regressions where the independent variables cannot influence each other as a biased result will be obtained. Using this method, the relationship between the dependent variables, which is capable of analyzing the data is determined. Furthermore, variables with a correlation of more than 0.8 or VIF $<10$ are eliminated.

The T-test is an analytical framework used to determine the difference between two sample averages from two normally distributed and unknown variances ${ }^{23)}$. stated that the purpose of the partial test is to determine the influence of the independent variable $(\mathrm{X})$ on the dependent variable $(\mathrm{Y})$. The level of significance or confidence often used in the t-test is $0.05(\alpha=5 \%)$ or 0.1 $(\alpha=10 \%)$. The t-test examines the association of independent with the dependent variable individually. It is also used to eliminate the independent with insignificant effects. In this study, the trust value used is $10 \%$.

According to De Smith ${ }^{24)}$, the $\mathrm{f}$ test, also known as simultaneous or ANOVA test, is used to determine the effect of all independent variables on the dependent. It also tests show the significance of variables in the regression model. De Smith ${ }^{24)}$ stated that the f Test shows all independent variables included in the model have a joint influence on the dependent variable. The level of significance or level of confidence often used is 0.05 ( $\alpha=$ $5 \%)$ or $0.1(\alpha=10 \%)^{25)}$.

\section{Results and Discussion}

All statistical calculations in this study use the help of IBM SPSS 23. The sequence used to determine the variables that affect residential prices is conducted in figure 2. This analysis need to follow that sequence because the output of the previous statistical analysis is taken into consideration variable, which is used in subsequent statistical analysis.

The first test carried out was a multicollinearity test or Pearson correlation between variables. The rejected Pearson correlation value in this test is the relationship between the independent variables that exceed 0.8 because the number indicates a very strong relationship. One of the conditions of linear regression is that there should not be an independent variable that correlates strongly. 
Tabel 4. Pearson Correlation of Variables Part I

\begin{tabular}{lrrrrrrr}
\hline Variables & Ln_P & UA & SBA & SLA & BA & LA & Dens \\
\hline Ln_P & 1 & $0.142^{* *}$ & $0.134^{* *}$ & $0.167^{* *}$ & $0.158^{* *}$ & $0.032^{* *}$ & -0.020 \\
UA & $0.142^{* *}$ & 1 & 0.869 & 0.831 & -0.301 & -0.320 & -0.046 \\
SBA & $0.134^{* *}$ & $0.869^{* *}$ & 1 & 0.611 & -0.276 & -0.293 & 0.019 \\
SLA & $0.167^{* *}$ & $0.831^{* *}$ & $0.611^{* *}$ & 1 & -0.271 & -0.287 & -0.093 \\
BA & $0.158^{* *}$ & $-0.301^{* *}$ & $-0.276^{* *}$ & $-0.271^{* *}$ & 1 & 0.682 & 0.179 \\
LA & $0.032^{* *}$ & $-0.320^{* *}$ & $-0.293^{* *}$ & $-0.287^{* *}$ & $0.682^{* *}$ & 1 & 0.121 \\
Dens & -0.020 & $-0.046^{* *}$ & 0.019 & $-0.093^{* *}$ & $0.179^{* *}$ & $0.121^{* *}$ & 1 \\
D_MRTJ & $-0.160^{* *}$ & -0.005 & 0.007 & -0.013 & $-0.044^{* *}$ & -0.010 & $0.069^{* *}$ \\
D_CBD & $-0.416^{* *}$ & 0.003 & 0.011 & $-0.041^{* *}$ & $-0.241^{* *}$ & $-0.124^{* *}$ & $-0.586^{* *}$ \\
D_MALL & $-0.134^{* *}$ & -0.019 & -0.009 & $-0.048^{* *}$ & $-0.069^{* *}$ & $-0.029^{* *}$ & $-0.236^{* *}$ \\
D_Hospital & -0.004 & $-0.040^{* *}$ & -0.011 & $-0.029^{* *}$ & $0.099^{* *}$ & $0.028^{* *}$ & $-0.086^{* *}$ \\
D_F.Highschool & $-0.113^{* *}$ & $-0.029^{* *}$ & 0.020 & $-0.070^{* *}$ & $0.181^{* *}$ & $0.090^{* *}$ & $0.784^{* *}$ \\
D_PublicPark & $0.073^{* *}$ & $0.102^{* *}$ & $0.070^{* *}$ & $0.143^{* *}$ & $0.055^{* *}$ & $-0.026^{*}$ & $-0.175^{* *}$ \\
D_F.Uni & $-0.203^{* *}$ & -0.010 & 0.018 & $-0.051^{* *}$ & $0.175^{* *}$ & $0.118^{* *}$ & $0.495^{* *}$ \\
\hline
\end{tabular}

** Correlation is significant at the 00.01 level (2-tailed).

* Correlation is significant at the 00.05 level (2-tailed).

Tabel 5. Pearson Correlation of Variables Part II

\begin{tabular}{llllllll}
\hline Variables & D_MRTJ & D_CBD & D_MALL & D_Hospital & D_F.Highschool & D_PublicPark & D_F.Uni \\
\hline Ln_P & $-0.160^{* *}$ & $-0.416^{* *}$ & $-0.134^{* *}$ & -0.004 & $-0.113^{* *}$ & $0.073^{* *}$ & $-0.203^{* *}$ \\
UA & -0.005 & 0.003 & -0.019 & -0.040 & -0.029 & 0.102 & -0.010 \\
SBA & 0.007 & 0.011 & -0.009 & -0.011 & 0.020 & 0.070 & 0.018 \\
SLA & -0.013 & -0.041 & -0.048 & -0.029 & -0.070 & 0.143 & -0.051 \\
BA & -0.044 & -0.241 & -0.069 & 0.099 & 0.181 & 0.055 & 0.175 \\
LA & -0.010 & -0.124 & -0.029 & 0.028 & 0.090 & $-0.026 *$ & 0.118 \\
Dens & 0.069 & -0.586 & -0.236 & -0.086 & 0.784 & -0.175 & 0.495 \\
D_MRTJ & 1 & 0.367 & 0.636 & 0.351 & 0.120 & 0.120 & 0.220 \\
D_CBD & $0.367 * *$ & 1 & 0.493 & 0.068 & -0.360 & 0.110 & -0.009 \\
D_MALL & $0.636^{* *}$ & $0.493^{* *}$ & 1 & 0.419 & -0.004 & 0.190 & 0.101 \\
D_Hospital & $0.351^{* *}$ & $0.068^{* *}$ & $0.419 * *$ & 1 & 0.273 & 0.563 & 0.145 \\
D_F.Highschool & $0.120^{* *}$ & $-0.360^{* *}$ & -0.004 & $0.273^{* *}$ & 1 & 0.222 & 0.703 \\
D_PublicPark & $0.120^{* *}$ & $0.110^{* *}$ & $0.190^{* *}$ & $0.563^{* *}$ & $0.222^{* *}$ & 1 & 0.198 \\
D_F.Uni & $0.220^{* *}$ & -0.009 & $0.101^{* *}$ & $0.145^{* *}$ & $0.703^{* *}$ & $0.198^{* *}$ & 1 \\
\hline
\end{tabular}

** Correlation is significant at the 0.01 level (2-tailed).

* Correlation is significant at the 0.05 level (2-tailed).

From tables 4 and 5, the control variables for structural attributes have a strong correlation with each other. Each apartment's structural attributes to controlling sizes, such as UA, SBA, and SLA, have very high correlations, while the relationship between UA-SBA and UA-SLA is 0.869 and 0.831 , respectively. Similar events also occur in the structural attributes that control the size of housing, with the BA-LA relationship at 0.682 . However, multicorrelation is used to eliminate the effects of bias when making predictions on unknown variables. The structural attribute is a variable used to control the size of a residential property and explains the reason for the significant correlation. The larger the unit size, the greater the proportion of ownership of land and shared buildings. However, the extent of ownership cannot be eliminated because it describes the luxury and facilities of the apartment unit. Therefore, it is specifically for structural attributes, although it has a high Pearson Correlation number, with its structural characteristics used for further statistical analysis and the model made using the output of this paper. Apart from structural attributes, there is no relationship between independent variables with more than 0.8 numbers, thereby utilizing all variables in the paired t-test analysis.

The paired t-test is used to analyze the relationship between 2 populations. In this study, it was used to test the significance of the dependent and independent variables in pairs. The results of the t-test are shown in table 6 . Based on the t-test analysis that has been conducted, it can be concluded that all independent variables are significantly associated in pairs $($ sig< $<.1)$. 
Table 6. Paired t-Test

\begin{tabular}{lrrrrr}
\hline & \multicolumn{3}{c}{ Paired Differences } & & Sig. (2- \\
\cline { 2 - 4 } Paired Samples Test & Mean & Std. Deviation & $\begin{array}{r}\text { Std. Error } \\
\text { Mean }\end{array}$ & t & $\begin{array}{r}\text { Siled) } \\
\hline \text { Ln_P - UA }\end{array}$ \\
\cline { 2 - 4 } Ln_P - SBA & 7.038 & 41.086 & 0.442 & 15.906 & 0.000 \\
Ln_P - SLA & 12.194 & 18.707 & 0.201 & 60.527 & 0.000 \\
Ln_P - LA & 12.235 & 18.865 & 0.203 & 60.221 & 0.000 \\
Ln_P - Dens & -241.629 & 173.391 & 1.867 & -129.398 & 0.000 \\
Ln_P - D_MRTJ & -13726.554 & 3151.714 & 33.942 & -404.407 & 0.000 \\
Ln_P - D_CBD & -700.135 & 635.309 & 6.842 & -102.329 & 0.000 \\
Ln_P - D_MALL & -2550.139 & 2520.425 & 27.144 & -93.949 & 0.000 \\
Ln_P - D_Hospital & -763.417 & 551.785 & 5.942 & -128.468 & 0.000 \\
Ln_P - D_F.Highschool & -870.426 & 488.199 & 5.258 & -165.554 & 0.000 \\
Ln_P - D_PublicPark & -3156.159 & 1505.739 & 16.216 & -194.632 & 0.000 \\
Ln_P - D_F.Uni & -983.791 & 457.442 & 4.926 & -199.697 & 0.000 \\
\hline
\end{tabular}

Table 7. ANOVA Test

\begin{tabular}{lrrrrr}
\hline & \multicolumn{2}{c}{$\begin{array}{c}\text { Unstandardized } \\
\text { Coefficients }\end{array}$} & $\begin{array}{c}\text { Standardized } \\
\text { Coefficients }\end{array}$ & \multicolumn{1}{c}{$\mathrm{t}$} & $\begin{array}{c}\text { Sig. (2- } \\
\text { tailed) }\end{array}$ \\
\cline { 2 - 4 } (Constant) & \multicolumn{1}{c}{ B } & Std. Error & \multicolumn{1}{c}{ Beta } & & \\
UA & 17.034 & 0.066 & & 259.473 & 0.000 \\
SBA & -0.002 & 0.000 & -0.092 & -3.357 & 0.001 \\
SLA & 0.008 & 0.001 & 0.216 & 11.116 & 0.000 \\
BA & 0.002 & 0.001 & 0.056 & 3.199 & 0.001 \\
LA & 0.001 & 0.000 & 0.180 & 14.437 & 0.000 \\
Dens & 0.000 & 0.000 & -0.067 & -5.528 & 0.000 \\
D_MRTJ & 0.000 & 0.000 & -0.262 & -10.943 & 0.000 \\
D_CBD & 0.000 & 0.000 & 0.091 & 6.708 & 0.000 \\
D_MALL & 0.000 & 0.000 & -0.712 & -48.292 & 0.000 \\
D_Hospital & 0.000 & 0.000 & 0.128 & 9.793 & 0.000 \\
D_F.Highschool & 0.000 & 0.000 & -0.109 & -8.336 & 0.000 \\
D_PublicPark & 0.000 & 0.000 & -0.198 & -8.672 & 0.000 \\
D_F.Uni & 0.000 & 0.000 & 0.154 & 12.847 & 0.000 \\
\hline
\end{tabular}

ANOVA is used to test the significance of the dependent variables with the independent simultaneously. This is conducted to eliminate independent variables that do not significantly affect the dependent variable when there are influences from other independent variables. Based on the
ANOVA results in table 7 , the distance from residential property to a favorite university does not significantly affect residential prices because it is significant and greater than 0.1 . Therefore, the variable distance is eliminated at this step.

Table 8. Final ANOVA Test (without D_F.Uni)

\begin{tabular}{|c|c|c|c|c|c|}
\hline & \multicolumn{2}{|c|}{$\begin{array}{l}\text { Unstandardized } \\
\text { Coefficients }\end{array}$} & \multirow{2}{*}{$\begin{array}{l}\text { Standardized } \\
\text { Coefficients } \\
\text { Beta }\end{array}$} & \multirow[t]{2}{*}{$\mathrm{t}$} & \multirow{2}{*}{$\begin{array}{l}\text { Sig. (2- } \\
\text { tailed) }\end{array}$} \\
\hline & $\mathrm{B}$ & Std. Error & & & \\
\hline (Constant) & 17.043 & 0.065 & & 262.124 & 0.000 \\
\hline UA & -0.002 & 0.000 & -0.093 & -3.378 & 0.001 \\
\hline SBA & 0.008 & 0.001 & 0.216 & 11.129 & 0.000 \\
\hline SLA & 0.002 & 0.001 & 0.056 & 3.186 & 0.001 \\
\hline BA & 0.001 & 0.000 & 0.178 & 14.418 & 0.000 \\
\hline LA & 0.000 & 0.000 & -0.067 & -5.563 & 0.000 \\
\hline Dens & 0.000 & 0.000 & -0.262 & -10.941 & 0.000 \\
\hline
\end{tabular}




\begin{tabular}{llllll} 
D_MRTJ & 0.000 & 0.000 & 0.089 & 6.645 & 0.000 \\
D_CBD & 0.000 & 0.000 & -0.716 & -50.538 & 0.000 \\
D_MALL & 0.000 & 0.000 & 0.128 & 9.839 & 0.000 \\
D_Hospital & 0.000 & 0.000 & -0.107 & -8.283 & 0.000 \\
D_F.Highschool & 0.000 & 0.000 & -0.209 & -10.436 & 0.000 \\
D_PublicPark & 0.000 & 0.000 & 0.153 & 12.810 & 0.000 \\
\hline
\end{tabular}

After the elimination of the distance to favorite university from the potential variables affecting residential property price, ANOVA test is repeated to test whether there are any other variables that need to be excluded due to its insignificant when other variables included. The result of final ANOVA test that can be seen in table 8 shows that every variable tested is significant, thus all the variables in table 8 are acceptable to be used in future research by developing model to predict the property prices.

\section{Conclusion}

Based on the analysis, it can be concluded that not all the variables that suspected to affect property prices will actually right. This study was made to select the best variables that can represent the residential property prices in the market. While all the initial variables were benchmarked from several paper which relevant with this study, those studies were made for another country or city that have different people with different human behavior. Thus, those variables need to be tested to show the show whether they really are the best fit for the model of Jakarta's residential property prices or not. The sequence of statistic test was used in this study and eliminate distance to favorite university from the significant variable list. This shows that not every variable that significant in another area is suitable for the model of residential property in Jakarta area. At last, the crucial variables capable of affecting the residential property surrounding MRT phase I prices are unit area, shared building, shared land, land area, building, density, distance to MRT/CBD/hospital/favorite high school, and public park. All variables passed in the multi, and Pearson Collinearity test except the structural attribute controls the size of the residential property. Furthermore, all independent variables were significant for the dependent in the paired t-test. The ANOVA test is used to eliminate the favorite university because it is not significant when influenced by other independent variables. Also, all independent variables, except the favorite university, are significant to the dependent. The residue from the ANOVA results was normally distributed, which showed that the distribution of the data was normal therefore, the requirements for Pearson Collinearity, t-test, and ANOVA were fulfilled

\section{Acknowledgement}

This research was supported by research grants from Universitas Indonesia and Ministry of Research and Higher Education, Republic of Indonesia.

\section{References}

1) M.A. Berawi, B. Susantono, P. Miraj, Gunawan, and A.E. Husin, "Conceptual design of sunda strait bridge using value engineering method,” in: Proc. Int. Conf. Value Eng. Manag. Innov. Value Methodol. ICVEM 2012, 2012.

2) S. Maimunah, and S. Kaneko, "MRT as Climate Policy in Urban Transportation,” in: Clim. Chang. Policies Challenges Indones., Springer, 2016: pp. 243-264.

3) M. Farda, and H. Lubis, "Transportation system development and challenge in jakarta metropolitan area, indonesia,” Int. J. Sustain. Transp. Technol, 1 (2) 42-50 (2018).

4) A.R. Sulaeman, and S. Haryadi, “Traffic Engineering and Grade of Service of Passenger Flow in LRT Palembang,” in: 2018 4th Int. Conf. Wirel. Telemat., IEEE, 2018: pp. 1-6.

5) C. Higgins, and P. Kanaroglou, "Rapid transit, transitoriented development, and the contextual sensitivity of land value uplift in toronto,” Urban Stud., (2018). doi:10.1177/0042098017712680.

6) S.I. Mohammad, D.J. Graham, P.C. Melo, and R.J. Anderson, "A meta-analysis of the impact of rail projects on land and property values," Transp. Res.

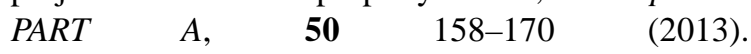
doi:10.1016/j.tra.2013.01.013.

7) D. Boyce, "Urban transit: operations, planning, and economics, edited by vukan r. vuchic,” J. Reg. Sci., (2006). doi:10.1111/j.1467-9787.2006.00453_2.x.

8) M.A. Berawi, B.E. Ibrahim, Gunawan, and P. Miraj, "Developing a conceptual design of transit-oriented development to improve urban land use planning," $J$. Des. Built Environ., 19 (1) (2019).

9) T. Sato, "How is a sustainable society established? a case study of cities in japan and germany," Evergreen, (2016). doi:10.5109/1800869.

10) B.G. Lane, "WRI working paper: governance of inclusive transit-oriented development in brazil," (January) 1-36 (2017). https://www.wri.org/publication/governanceinclusive-tod.

11) M.A. Berawi, N. Suwartha, K. Kurnia, Gunawan, P. 
Miraj, and A.R.B. Berawi, "Forecasting the land value around commuter rail stations using hedonic price modeling," Int. J. Technol., 9 (7) (2018). doi:10.14716/ijtech.v9i7.2589.

12) F. Medda, "Land value capture finance for transport accessibility: a review,” J. Transp. Geogr., (2012). doi:10.1016/j.jtrangeo.2012.07.013.

13) H. Suzuki, J. Murakami, Y.-H. Hong, and B. Tamayose, "Financing transit-oriented development with land values: Adapting land value capture in developing countries,” The World Bank, 2015.

14) M.O. Smolka, "Implementing Value Capture in Latin America: Policies and Tools for Urban Development Policy Focus Report Series,” 2013.

15) C.C. Huang, "Innovation in public transport finance: Property value capture,” 2014.

16) C. Mulley, and C.H. (Patrick) Tsai, "When and how much does new transport infrastructure add to property values? evidence from the bus rapid transit system in sydney, australia,” Transp. Policy, (2016). doi:10.1016/j.tranpol.2016.01.011.

17) J. McIntosh, R. Trubka, and P. Newman, “Can value capture work in a car dependent city? willingness to pay for transit access in perth, western australia," Transp. Res. Part A Policy Pract., (2014). doi:10.1016/j.tra.2014.07.008.

18) A. Roukouni, C. Macharis, S. Basbas, B. Stephanis, and G. Mintsis, "Financing urban transportation infrastructure in a multi-actors environment: the role of value capture," Eur. Transp. Res. Rev., (2018). doi:10.1007/s12544-017-0281-5.

19) R. Kimura, "Social or business or 'social and business': problematique of the hybrid structure of community-based ecotourism in cambodia," Evergreen, (2017). doi:10.5109/1929664.

20) D. Salon, and S. Shewmake, "Opportunities for value capture to fund public transport: a comprehensive review of the literature with a focus on east asia," SSRN Electron. J., (2012). doi:10.2139/ssrn.1753302.

21) D.A. Rodríguez, and C.H. Mojica, "Capitalization of brt network expansions effects into prices of nonexpansion areas," Transp. Res. Part A Policy Pract., $43 \quad$ (5) 560-571 (2009). doi:10.1016/j.tra.2009.02.003.

22) M. Zhang, and T. Xu, "Uncovering the potential for value capture from rail transit services,” J. Urban Plan. Dev., $143 \quad$ (3) $04017006 \quad$ (2017). doi:10.1061/(ASCE)UP.1943-5444.0000383.

23) C.A. Boneau, "The effects of violations of assumptions underlying the test," Psychol. Bull., (1960). doi:10.1037/h0041412.

24) M.J. De Smith, "Statistical Analysis Handbook A Comprehensive Handbook of Statistical Concepts, Techniques and Software Tools/Dr Michael J de Smith, 2018, The Winchelsea Press,” The Winchelsea Press, 2018.

25) W.K. Härdle, and L. Simar, “Applied multivariate statistical analysis,” 2013. doi:10.1007/978-3-64217229-8. 